\title{
Prevalence of upper respiratory diseases and associated factors in Colombian Creole horses
}

\author{
[Prevalência de doenças do trato respiratório superior e fatores associados \\ em Cavalos Crioulos colombianos] \\ C. Jaramillo ${ }^{1}$, M.P. Arias Gutierrez ${ }^{2}$ \\ ${ }^{1}$ GIVET research group, Veterinary Medicine Program - Corporacion Universitaria \\ Lasallista - Caldas - Antioquia, Colombia \\ ${ }^{2}$ Faculty of Veterinary Medicine and Animal Sciences - Universidad CES \\ (CES University) - Calle 10 a \# 22-04-Medellin, Colombia
}

\begin{abstract}
To determine the prevalence of diseases of the upper respiratory tract and associated factors in the Colombian Creole Horse Valley Aburrá in 2015, a random sampling of 15 farms in southern Aburrá Valley under different management conditions was performed. A total of 105 CCC underwent general clinical examination, respiratory endoscopic evaluation and a detailed inspection of housing conditions and management. A low prevalence of upper respiratory tract diseases was observed, including Pharyngeal Lymphoid Hyperplasia 38.1\%, Recurrent Laryngeal Neurophaty 12.38\%, Dorsal Displacement of the Soft Palate $7.62 \%$, and presence of tracheal secretions not associated with a specific pathology. A bivariate analysis showed association between tracheal secretions and frequency of training per week $(\mathrm{OR}=9.86)$, duration of the training sessions $(\mathrm{OR}=5.55)$ and inadequate ventilation of the stable $(\mathrm{OR}=10.52)$. Association between HLR and inadequately ventilated barns was also observed (OR $=14.9)$. Logistic regression showed association between tracheal secretions and inadequate ventilation $(\mathrm{OR}=7.18)$. We conclude that inadequate ventilation was the most important factor for the incidence of upper respiratory tract diseases in horses at the southern area of the Aburrá Valley.
\end{abstract}

Keywords: equine, respiratory diseases, handling, ventilation

\section{RESUMO}

O presente trabalho objetivou determinar a prevalência das doenças do trato respiratório superior e fatores associados no cavalo Crioulo colombiano do Vale de Aburrá, em 2015. Uma amostra aleatória de 15 fazendas no sul do Vale de Aburrá, sob diferentes condições de manutenção, foi realizada. Cento e cinco CCC foram submetidos a exame clínico geral, à avaliação endoscópica respiratória e a uma inspeção detalhada das condições habitacionais. Observou-se uma baixa prevalência de doenças do trato respiratório superior, incluindo hiperplasia faríngea linfoide 38.1\%, neuropatia laríngea recorrente $12.38 \%$, deslocamento dorsal do palato mole $7.62 \%$ e presença de secreção traqueal não associada a uma patologia específica. A análise bivariada mostrou associação entre secreção traqueal e frequência de treinamento por semana $(O R=9.86)$, duração das sessões de treinamento $(O R=5.55)$ e ventilação inadequada do estábulo $(O R=10.52)$. Associação entre HLR e boxes inadequadamente ventilados também foi observada $(O R=14.9)$. A regressão logística mostrou associação entre secreção traqueal e ventilação inadequada $(O R=7.18)$. Conclui-se que a ventilação inadequada foi o fator mais importante para a incidência de doenças do trato respiratório superior em cavalos na zona sul do Vale do Aburrá.

Palavras-chave: equinos, doenças respiratórias, manipulação, ventilação

Recebido em 13 de dezembro de 2016

Aceito em 19 de janeiro de 2017

E-mail: cajaramillo@lasallistadocentes.edu.co 


\section{INTRODUCTION}

Musculoskeletal problems are the first cause of athletic deficit in horses in the world and respiratory tract diseases are the second cause (Reed et al., 2010). Oxygen consumption increases dramatically during exercise to maintain homeostasis of gas exchange and prevent metabolic disorders. Upper respiratory tract diseases (URT) interfere with airflow and oxygen consumption $\left(\mathrm{VO}_{2}\right)$, which is reflected as intolerance to exercise and decreased work capacity in high-performance horses, such as those competing on tracks (Rush and Mair, 2004; Hodgson et al., 2014).

Withdrawal from competition and suspension of training due to respiratory conditions can entail important economic losses; hence, early diagnosis and early treatment of respiratory conditions are required for a rapid return to competition (Parente, 2010).

The Colombian Creole horse used for track competitions is continuously exposed to stressful conditions, such as transport from the farm to the competition track which sometimes involves long trips. Changes in accommodation and feed, contact with other horses, and high athletic demands predispose track horses to clinical and sub-clinical respiratory diseases Oliver and Martinez, 2012).

Sub-clinical diseases of the URT affect performance in competition horses and occur under acute stress, as seen in competitions in which horses are reluctant to work or when they exhibit exercise intolerance (Hodgson et al., 2014). A general clinical examination does not usually include visual inspection of the upper respiratory tract by ancillary tests such as endoscopy, unless there are evident symptoms. Therefore, lesions in the upper respiratory tract are commonly diagnosed only when horse performance decreases on the track (Hodgson et al., 2014; Smith, 2015).

Oliver and Martinez (2012) described RLN and DDSP as the most common conditions in Colombian Creole horses in the Bogotá region. We are not aware of other publications documenting the frequency of upper tract respiratory diseases in horses with decreased athletic performance, nor on the risk factors associated with these pathologies.
It is important to achieve early diagnosis regarding to what extent exercise intolerance of horses on the track is due to URT diseases, and identify the associated epidemiological factors. This can help not only to take preventative measures to reduce its incidence, but also to avoid long disability periods and ensuing economic losses (Roy and Lavoie, 2003). The objective of this study was to establish the prevalence of upper respiratory tract diseases in Colombian Creole horses and its associated factors.

\section{MATERIALS AND METHODS}

A descriptive, observational and cross-sectional study was conducted in the southern area of Aburrá Valley. The Metropolitan Area of Aburrá Valley is an administrative and political region that reunites ten municipalities of Antioquia province (Colombia). Its core is Medellin (province capital). The study included the southern municipalities of the Metropolitan Area, namely: Caldas, La Estrella, Itagui, Sabaneta and Envigado. San Antonio de Prado (a Medellin district) was also included. These areas were selected for their high population of Colombian Creole horses. A total of 105 male and female Colombian Creole horses were randomly sampled from 15 horse farms. The horses were under training for track competitions.

The variables analyzed were: gender, age [youth ( 3 to 5 years), adult (6 to 14 years), and geriatric horses (over 18 years)], habitat [grazing or confinement], type of stable [open (with ventilation) or closed (without ventilation)], bedding material [sawdust or wood shavings], inclusion of hay in the diet, training or work frequency per week, hours or training per session, number of trips to the track per year, ventilation of the stable, nasal secretions (any secretion), presence of cough, decreased performance, exercise intolerance, pulmonary rales, cough reflex, and endoscopy findings.

Information was initially collected on the general accommodation and management conditions of horses to establish the associated variables. Subsequently, both general and special clinical examinations of the respiratory system were performed. Endoscopy included an evaluation of congestion, hemorrhages and secretions in all the anatomical structures of the respiratory tract. 
Additionally, sinusitis, rhinitis, polyps, hematoma and other lesions were diagnosed in the right and left nasal cavities. Wall integrity, pharyngeal collapse, intermittent DDSP, lymphoid hyperplasia, and other lesions were evaluated in the nasopharynx. Larynx was checked for integrity of the arytenoid cartilage, epiglottis, rima glottidis, and vocal process, as well as for the presence of laryngeal hemiplegia, chondritis, arytenoid cysts, epiglottic entrapment and other lesions. The trachea walls were evaluated for the presence of tracheal collapse, granulomas, chondritis, foreign body and other lesions.

Horses were sedated after previous evaluation with $0.5 \mathrm{mg} / \mathrm{kg}$ Xylazine combined with intravenous $0.02 \mathrm{mg} / \mathrm{kg}$ Acepromazine. The procedure was resumed ten minutes after sedation by initially entering through the right nostril and crossing the ventral meatus to reach the nasopharynx. The endoscope went through the cartilaginous flap of the guttural pouch ostia to reach the right guttural pouch making a $180^{\circ}$ turn to prevent the tip of the endoscope to get trapped in the ostium of the auditory canal. Subsequently, the same procedure was performed through the left nostril to reach the left guttural pouch. Conformation and possible pathologies were evaluated in each guttural pouch (plica salpingo-pharyngea, and presence of chondroid, hematomes, fungal infections, tympanism or other injuries in each compartment). Endoscopy procedures were performed with a $15 \mathrm{~mm}$ Portascope PSV $3 \mathrm{M} \AA$ equipment (Bradenton, FL, USA). Endoscopy findings were sent to farm owners, along with a recommendation to consult with a veterinarian in case horses presented respiratory disorders.

The database was built on Microsoft Excel® software and statistical analysis was performed in Stata (version 13.0). Univariate analysis was performed for qualitative variables, and expressed as absolute and relative frequencies. A bivariate analysis was performed to detect association between dependent variables (upper respiratory findings) and each independent variable. $2 \times 2$ tables were made to obtain odds ratios (OR), taking into account the confidence intervals. Statistical significance was considered at $P<0.05$. Finally, variables associated with different outcomes were included in a binary logistic regression model.

\section{RESULTS}

In this study different management and accommodation conditions were observed (Fig. 1). Most animals (53.85\%) were in good body condition (7/9).

Of the horses, $58.1 \%$ were females, although sex was not associated with any condition. In general, young horses had less upper respiratory tract alterations than adult and geriatric animals. Regarding diet, hay consumption was low $(3.81 \%)$. Variables were validated by descriptive statistics and showed normal distribution. Table 1 shows population features and management.

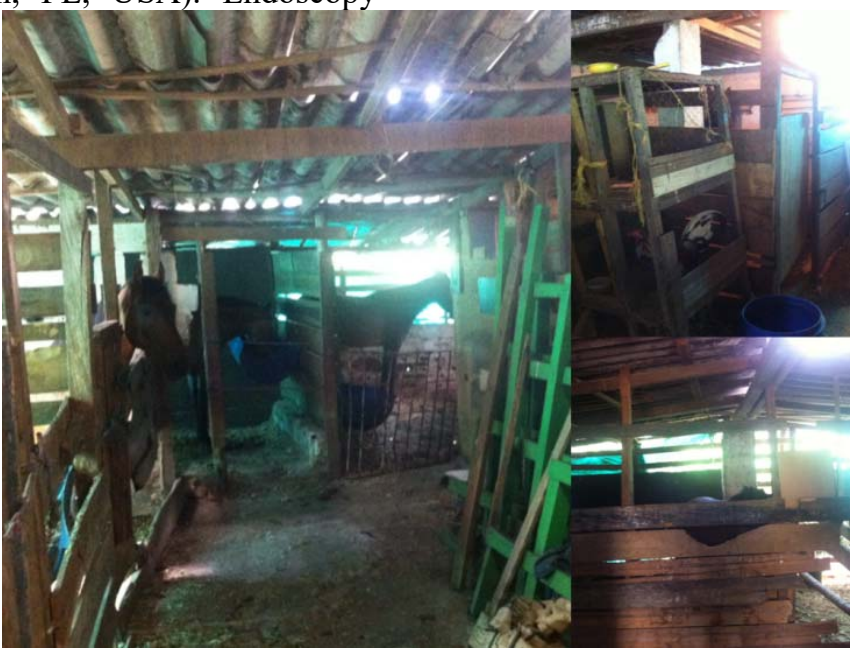

Figure 1. Inadequate ventilation in one of the farms showing accumulation of debris and presence of other animal species stabled with the horses. 
Table 1. Distribution of animal characteristics and management conditions in the study

\begin{tabular}{|c|c|c|c|}
\hline Variable & Categories & Number & Percentage \\
\hline \multirow[t]{2}{*}{ Sex } & Male & 44 & $42 \%$ \\
\hline & Female & 61 & $58 \%$ \\
\hline \multirow[t]{3}{*}{ Age group } & Young & 51 & $48 \%$ \\
\hline & Adult & 49 & $47 \%$ \\
\hline & Geriatric & 5 & $5 \%$ \\
\hline \multirow[t]{5}{*}{ Body score } & $5 / 9$ & 15 & $1.4 \%$ \\
\hline & $6 / 9$ & 19 & $1.8 \%$ \\
\hline & 7/9 (ideal) & 56 & $53.8 \%$ \\
\hline & $8 / 9$ & 13 & $5 \%$ \\
\hline & $9 / 9$ & 1 & $1 \%$ \\
\hline \multirow[t]{5}{*}{ Horses per municipality } & Caldas & 43 & $41 \%$ \\
\hline & Envigado & 10 & $9 \%$ \\
\hline & La Estrella & 31 & $30 \%$ \\
\hline & Sabaneta & 10 & $10 \%$ \\
\hline & San Antonio de Prado & 11 & $10 \%$ \\
\hline \multirow[t]{2}{*}{ Housing } & Stable & 92 & $88 \%$ \\
\hline & Paddock & 13 & $12 \%$ \\
\hline \multirow[t]{3}{*}{ Accommodation } & Roofed stable & 56 & $53 \%$ \\
\hline & Open-roof corral & 36 & $35 \%$ \\
\hline & Paddock & 13 & $12 \%$ \\
\hline \multirow[t]{2}{*}{ Ventilation } & Adequate & 52 & $50.4 \%$ \\
\hline & Inadequate & 53 & $49.5 \%$ \\
\hline \multirow[t]{3}{*}{ Bedding } & Wood shavings & 68 & $64.8 \%$ \\
\hline & Sawdust & 24 & $22.9 \%$ \\
\hline & Paddock & 13 & $12.4 \%$ \\
\hline \multirow[t]{2}{*}{ Hay inclusion in the diet } & Yes & 4 & $3.8 \%$ \\
\hline & No & 101 & $96.2 \%$ \\
\hline \multirow[t]{2}{*}{ Trips per week } & Yes & 2 & $1.9 \%$ \\
\hline & No & 103 & $98.1 \%$ \\
\hline \multirow{2}{*}{ Exercise (days per week) } & $\geq 3$ days & 30 & $28.6 \%$ \\
\hline & $<3$ days & 75 & $71.4 \%$ \\
\hline \multirow[t]{2}{*}{ Duration of routine (training) } & $<1$ hour & 21 & $20 \%$ \\
\hline & $\geq 1$ hour & 84 & $80 \%$ \\
\hline
\end{tabular}

Few horses showed respiratory symptoms: $2.86 \%$ showed positive cough reflex, two $(1.90 \%)$ had respiratory noises and one $(0.95 \%)$ nasal serous discharge.

No lesions were observed in guttural pouches; however, some horses had moderate to abundant mucus secretion in the left and right cartilaginous flap of the guttural pouch ostia (Figure 2a).

Nasopharynx alterations corresponded to congestion $2.86 \%$ and DDSP $7.62 \%$. PLH seen in $38.1 \%$ of the horses (Figure $2 \mathrm{~b}$ and $2 \mathrm{c}$ ). The distribution of this condition is presented in Table 2 .

Larynx congestion was observed in one horse $(0.95 \%)$ and laryngeal edema in other equine. HLR was present in $12.38 \%$ of patients. Tab. 2 shows the distribution of the condition.

$5.71 \%$ of the horses showed tracheal mucosa congestion. $2.85 \%$ of the horses had tracheal collapse (Figure 2d). 
Prevalence of upper...

Table 2. Description of the upper respiratory tract findings in the studied population.

\begin{tabular}{|c|c|c|c|}
\hline Variable & Categories & $\begin{array}{c}\text { Number of } \\
\text { cases }\end{array}$ & Percentage \\
\hline \multirow{5}{*}{$\begin{array}{l}\text { Secretions observed in the turbinates of the } \\
\text { right and left nasal cavity }\end{array}$} & Normal & 98 & $93 \%$ \\
\hline & Congested & 2 & $2 \%$ \\
\hline & Congested and mucus & 1 & $1 \%$ \\
\hline & Mucus secretion & 2 & $2 \%$ \\
\hline & Fungal plaques & 1 & $1 \%$ \\
\hline \multirow[t]{5}{*}{ Secretions in the ethmoid turbinates } & Normal & 99 & $94 \%$ \\
\hline & Congested & 2 & $2 \%$ \\
\hline & Congested and mucus & 1 & $1 \%$ \\
\hline & Mucus secretion & 2 & $2 \%$ \\
\hline & Fungal plaques & 1 & $1 \%$ \\
\hline \multirow{4}{*}{$\begin{array}{l}\text { Presence of mucus in the right plica } \\
\text { pharyngea } \\
\text { Presence of mucus in the left plica pharyngea }\end{array}$} & Yes & 102 & $97.1 \%$ \\
\hline & No & 3 & $2.9 \%$ \\
\hline & Yes & 103 & $98.1 \%$ \\
\hline & No & 2 & $1.9 \%$ \\
\hline \multirow{3}{*}{$\begin{array}{l}\text { Distribution of secretions in the } \\
\text { right and left cartilaginous flap of the guttural } \\
\text { pouch ostia }\end{array}$} & Normal & 102 & $97 \%$ \\
\hline & Moderate mucus & 2 & $2 \%$ \\
\hline & Abundant mucus & 1 & $1 \%$ \\
\hline \multirow[t]{2}{*}{ Presence of mucus in the trachea } & Yes & 33 & $31.4 \%$ \\
\hline & No & 72 & $68.6 \%$ \\
\hline \multirow[t]{2}{*}{ DDSP } & Yes & 8 & $7.6 \%$ \\
\hline & No & 97 & $92.4 \%$ \\
\hline \multirow[t]{2}{*}{ RLN } & Yes & 13 & $12.4 \%$ \\
\hline & No & 92 & $87.6 \%$ \\
\hline \multirow[t]{4}{*}{ RLN distribution (degrees) } & No & 92 & $87.6 \%$ \\
\hline & II degree & 7 & $7 \%$ \\
\hline & III degree & 5 & $5 \%$ \\
\hline & IV degree & 1 & $1 \%$ \\
\hline \multirow[t]{2}{*}{ PLH } & Yes & 40 & $38 \%$ \\
\hline & No & 65 & $62 \%$ \\
\hline \multirow[t]{4}{*}{ PLH distribution (degrees) } & No & 65 & $62 \%$ \\
\hline & I degree & 21 & $20 \%$ \\
\hline & II degree & 12 & $11 \%$ \\
\hline & III degree & 7 & $7 \%$ \\
\hline \multirow[t]{2}{*}{ Tracheal collapse } & Yes & 3 & $2.9 \%$ \\
\hline & No & 102 & $97.1 \%$ \\
\hline
\end{tabular}
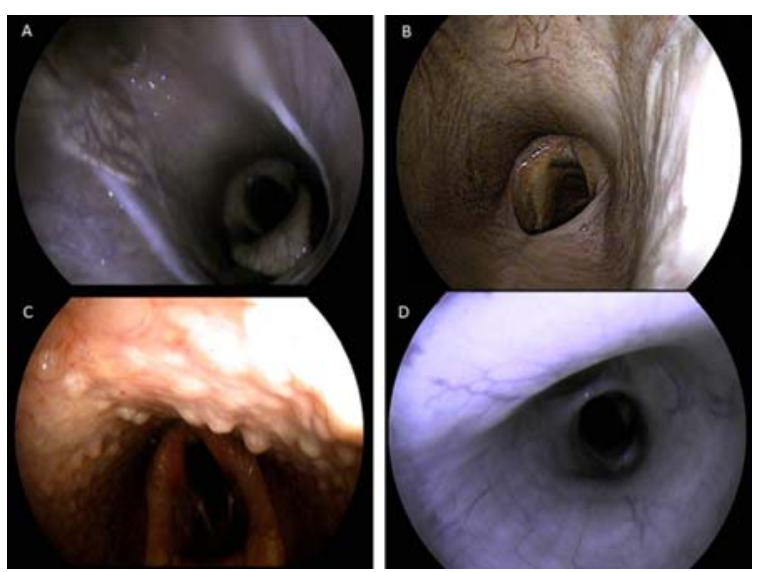

Figure 2. Injuries found through endoscopy in different structures of the upper respiratory tract. A. Abundant mucus secretion through the bilateral cartilaginous flap of the guttural pouch ostia. B. Intermittent DDSP (note that the epiglottis is not evidenced). C. PLH (III degree). D. Moderate tracheal collapse at the carina level. 
Bivariate analysis showed association between presence of tracheal secretions with training frequency, number of training hours, ventilation, and bedding, as shown in Tab. 3. The strongest association was with inadequate ventilation, with
10.5 OR, meaning that stabled horses with inadequate ventilation were 9.5 times more likely to suffer from tracheal secretions compared to those occupying well-ventilated housing.

Table 3. Factors associated with tracheal secretions according to the bivariate analysis

\begin{tabular}{|c|c|c|c|c|c|c|c|}
\hline \multirow[b]{2}{*}{ Facto } & & \multicolumn{2}{|c|}{$\begin{array}{c}\text { Tracheal } \\
\text { secretions }\end{array}$} & \multicolumn{4}{|c|}{$\begin{array}{c}\text { Confidence Interval } \\
95 \%\end{array}$} \\
\hline & & Yes & No & OR & $\begin{array}{l}\text { Lower } \\
\text { limit }\end{array}$ & Upper limit & $\begin{array}{c}P- \\
\text { value }\end{array}$ \\
\hline \multirow{4}{*}{$\begin{array}{l}\text { Training frequency } \\
\text { Duration of exercise } \\
\text { (training) }\end{array}$} & $\geq 3$ days & 31 & 44 & & & & \\
\hline & $<3$ days & 2 & 28 & 9.864 & 2.187 & 44.488 & 0.010 \\
\hline & $\geq 1$ hora & 31 & 53 & & & & \\
\hline & $<1$ hora & 2 & 19 & 5.557 & 1.212 & 25.481 & 0.016 \\
\hline \multirow{3}{*}{ Ventilation } & Inadequate & 28 & 25 & 10.52 & & & \\
\hline & Adequate & 5 & 47 & $\begin{array}{c}10.32 \\
8\end{array}$ & 3.618 & 30.635 & 0.000 \\
\hline & Sawdust & 31 & 37 & & & & \\
\hline Bedding & Wood shavings & 2 & 22 & 9.216 & 2.007 & 42.315 & 0.001 \\
\hline
\end{tabular}

An association was also found between more than three days of training per week and the presence of PLH $(\mathrm{OR}=8.7 ; 95 \%$ CI $(2.45$, 31.39); $P=0.000)$. An association was observed between RLN and housing in inadequately ventilated stables $(\mathrm{OR}=14.9 ; 95 \%$ CI $(1.86$, 119.6); $P=0.010)$.

The logistic regression model was only performed for the presence of tracheal secretions, as this was the principal factor associated with more than one risk factor in the bivariate analysis. This outcome was associated only with inadequate ventilation $(\mathrm{OR}=7.18 ; 95 \% \mathrm{CI}$ (2.36; 21.81); $P=0.001)$.

\section{DISCUSSION}

Even though most of the patients used for this study were females, this fact did not evidence any association with any pathology of the upper respiratory airway.

In all the farms that were visited, hay inclusion into the horses' diet was low, only $3.81 \%$. This condition is probably due to the extensive areas planted with tall-grass species in the region and the use of feed pellets in some farms.

Among the patients included in this study, only $5.71 \%$ showed respiratory symptomatology.
While respiratory diseases are a frequent cause of veterinary consultation, horses usually show symptoms when the disease is advanced. Presence of respiratory signs in subclinical diseases is rather scarce, as found in this study (Reed, 2010; Smith, 2015; Martinez and Oliver, 2012).

Pathologies of the cartilaginous flap of the guttural pouch ostia are more common in temperate countries because of the strong weather changes between seasons. No guttural pouch lesions were observed in this study, probably associated with the climatic stability of the region (Roy and Lavoie, 2003; Hardy and Léveillé, 2003).

Mucus secretion through the cartilaginous flap of the guttural pouch entrance often results from influenza virus associated with bacterial infections by Streptococcus equi var equi or Streptococcus equi var zooepidemicus (Gilkerson et al., 2015; Waller et al., 2011; Mallicote, 2015). Guttural pouch pathologies in Colombian Creole horses presented low frequency. However, future studies should involve more age groups and management diversity to evaluate this condition with greater certainty (Hardy and Léveillé, 2003).

The DDSP prevalence was $7.62 \%$ in the studied 
horses, the diagnosis of this pathology should be performed by dynamic endoscopy; however, some authors claim it can be diagnosed in a standing horse by performing manual occlusion of the nostrils (Parente et al., 2002), as we did in this study. Davidson and Martin (2003) reported $7.5 \%$ DDPB incidence in sport horses, which is very similar to our results, demonstrating the feasibility to reliably diagnose this and other dynamic pathologies, such as HLR, through endoscopy in standing horses (Heffron and Baker, 1979).

The PLH is a chronic inflammation of the pharynx lymphatic system that affects sport horses (Heffron and Baker, 1979). A study conducted in thoroughbred racing horses in South Africa detected $63 \%$ prevalence for this condition. The high prevalence in that study could be explained by the greater physical demands of that sport and the environmental conditions of a temperate country (Barakzai, 2006). On the contrary, a study on racing horses conducted at a racing track in Venezuela found a low prevalence for this condition (13.69\%) (Saulez and Gummow, 2009). This indicates that the type of sport and environmental conditions could be related to this disease, but more studies are needed to confirm it.

RLN is an abduction dysfunction of the arytenoid cartilage, corresponding to a mononeuronal and bilateral distal neuropathy, which mostly affects the left side. The cause is still unclear (Semeco et al., 2011; Hahn et al., 2008). Brakenhoft et al. (2006) reported 35\% RLN prevalence in 183 cold-blooded horses (Belgians, Percherons and Clydesdele) evaluated in Michigan (USA) (Davenport-Goodall and Parente, 2003). Their findings differ with our results probably because of the different breeds evaluated, since this disease is most often associated with large breeds. Large breeds, which have broader chest and longer neck, are more predisposed to develop RLN (19). However, despite being of short stature, this study and a report by Martinez and Oliver (2012) found that Colombian Creole horses also suffer from this pathology and it is considered of diagnostic significance. Probably the position of the neck (excessively flexed) during competitions and training of Colombian Creole horses predisposes them to develop RLN, possibly due to a compression and ischemia on the recurrent laryngeal nerve; more studies are needed to determine the specific causes (Brakenhoff et al., 2006).

Mucous tracheal secretion and congestion in some can be related to different conditions like intense exercising or upper airway pathologies, in this study the prevalence found was low, $5.71 \%$ (Morley et al., 2014). The tracheal collapse generates obstructive disorders, which worsens with stressors such as exercise, pregnancy, feeding and dusty environments. According to the literature, tracheal collapse has low prevalence and is more common in smallsize horses such as the Colombian Creole. The frequency observed in this study is similar to that reported in the literature for horses of the same size (Aleman et al., 2008; Tetens et al., 2000).

In this study tracheal secretions were associated with the following factors: week exercising frequency, exercising time (hours), ventilation, and sawdust bedding. It is known that inadequate ventilation and sawdust bedding cause discomfort, which favors respiratory pathologies since horse airways are particularly sensitive to dust. Dust from sawdust bedding generates chronic inflammation of the airways, resulting in goblet cell metaplasia, which express MUC5AC protein responsible for mucus production (Oslund et. al., 2010).

According to Halliwell et al. (1993), respiratory problems are closely associated with the presence of dust and fungal spores in the air, which is reflected in a variety of signs such as cough, abnormal breathing and eye discharges. High ammonia concentrations resulting from inadequate bedding materials can also cause respiratory problems, as described by Clarke (1987).

Similar to this study, other researchers have reported PLH in athlete horses aged two to four years which exercised more than three times a week (McAllister and Blakeslee, 1977). It is probable that stress caused by exercise predisposes to pharyngeal colonization by equine Herpesvirus 1 and 2 or to other agents involved with this pathology. As reported in the literature, horses with PLH usually do not develop this disease to an advanced degree, which was also evidenced in the present study (Reed, 2010). 
RLN is caused by a neuropathy of the recurrent laryngeal nerve. Although several possible causes of this disease have been studied, they are not conclusive (Cahill and Goulden, 1987; Chalmers et al., 2012). Our data suggests that horses kept in an inadequately ventilated stable are 13.9 times more likely to suffer this condition. However, other studies should be conducted to establish the etiology and disease mechanism. As RLN has a high frequency in Colombian Creole horses, it should be considered when snoring horses and low performance are taken to the veterinarian for examination (Holcombe et al., 2001).

Although prevalence of respiratory diseases and associated epidemiological factors are valid for horses located in the south of Aburrá Valley, these results can serve as a starting point to implement animal welfare programs and improve health conditions of Colombian Creole horses used for sport and recreation. Based on these results, we propose several easy to implement management changes, such as improving ventilation conditions in stables because a high percentage of them lacked adequate airflow, and this was the main factor associated with respiratory pathologies in the area.

Establishing the epidemiological factors associated with different respiratory diseases would greatly contribute to the knowledge by field veterinarians about possible complications of sub-optimum horse management. Considering the increasing number of horse farms in this area, there is a need to advise breeders on environmental issues to ensure that this does not pose a risk to horse health.

Telemetric endoscopy should be included in future studies of the upper air-tract pathologies to better understand the prevalence of dynamic diseases.

\section{CONCLUSION}

Inadequate ventilation and use of sawdust for bedding predispose to tracheal secretions and other disorders such as RLN. Adequate ventilation implies airflow with permanent and stable air currents, without overexposing the horses. RLN should be considered for differential diagnosis when snoring and low performance Colombian Creole horses are taken to the veterinarian. This study was approved by the Institutional Ethics Committee of Universidad CES, Colombia (CICUA), Act No. 4 of June 4, 2013. CICUA approved the consent inform signed by the horse owners.

\section{ACKNOWLEDGEMENTS}

We wish to thank the farmers who made this study possible. Special thanks to Erica Tatiana Loaiza for her important contributions. Thanks also to Manuela Montoya, Pablo Agudelo Agudelo, Jonathan Zapata Marin, as well as to our project partners and the Lasallian University Corporation students who collaborated with the study.

\section{REFERENCES}

ALEMAN, M.; JORGE NIETO, E.; BENAK, J.; JOHNSON, L.R. Tracheal collapse in American miniature horses: 13 cases (1985-2007). J. Am. Vet. Med. Assoc., v.233, p.1302-1306, 2008

BARAKZAI, S. Handbook of equine respiratory endoscopy. New York: Elsevier Saunders; 2006. $144 \mathrm{p}$.

BRAKENHOFF, J.E.; HOLCOMBE, S.J.; HAUPTMAN, J.G. et al. The prevalence of laryngeal disease in a large population of competition draft horses. Vet. Surg., v.35, p.57983, 2006

CAHILL, J.I.; GOULDEN, B.E. The pathogenesis of equine laryngeal hemiplegia-a review. N. Z. Vet. J., v.35, p.82-90, 1987

CHALMERS, H.J.; YEAGER, A.E.; CHEETHAM, J.; DUCHARME, N. Diagnostic sensitivity of subjective and quantitative laryngeal ultrasonography for recurrent laryngeal neuropathy in horses. Vet. Radiol. Ultrasound, v.53, p.660-666, 2012

CLARKE, A.F. A review of environmental and host factors in relation to equine respiratory disease. Equine Vet. J., v.19, p.435-441, 1987

DAVENPORT-GOODALL, C.L.; PARENTE, E.J. Disorders of the larynx. Vet. Clin. N. Am. Equine Pract., v.19, p.169-187, 2003 
DAVIDSON, E.J.; MARTIN, B.B. Diagnosis of upper respiratory tract diseases in the performance horse. Vet. Clin. N. Am. Equine Pract., v.19, p.51-62, 2003.

GILKERSON, J.R.; BAILEY, K.E.; DIAZMÉNDEZ, A.; HARTLEY, C.A. Update on viral diseases of the equine respiratory tract. Vet. Clin. N. Am. Equine Pract., v.31, p.91-104, 2015.

HAHN, C.N.; MATIASEK, K.; DIXON, P.M. et al. Histological and ultrastructural evidence that recurrent laryngeal neuropathy is a bilateral mononeuropathy limited to recurrent laryngeal nerves. Equine Vet. J., v.40, p.666-672, 2008.

HALLIWELL， R.E.; MCGORUM, B.C.; IRVING, P.; DIXON, P.M. Local and systemic antibody production in horses affected with chronic obstructive pulmonary disease. Vet Immunol. Immunopathol., v.38, p.201-215, 1993.

HARDY, J.; LÉVEILLÉ, R. Diseases of the guttural pouches. Vet. Clin. N. Am. Equine Pract., v.19, v.123-158, 2003.

HEFFRON, C.J.; BAKER, G.J. Observations on the mechanism of functional obstruction of the nasopharyngeal airway in the horse. Equine Vet. J., v.11, p.142-147, 1979.

HODGSON, D.R.; MCKEEVER, K.H.; MCGOWAN, C.M. (Eds.) The athletic horse: principles and practice of equine sports medicine. 2.ed. St. Louis: Saunders Elsevier, 2014. 396p.

HOLCOMBE, S.J.; JACKSON, C.; GERBER, V. et al. Stabling is associated with airway inflammation in young Arabian horses. Equine Vet. J., v.33, p.244-249, 2001.

MALLICOTE, M. Update on Streptococcus equi subsp equi infections. Vet. Clin. N. Am. Equine Pract. v.31, p.27-41, 2015.

MARTÍNEZ, D.; OLIVER, O. Estudio retrospectivo de las afecciones obstructivas de las vías aéreas superiores en equinos adultos presentados a la clínica para grandes animales de la Universidad Nacional de Colombia entre 1993 y 2007. Rev. Med. Ve.t Zootec., v.59, p.143-150, 2012.

MCALLISTER, E.S.; BLAKESLEE, J.R. Clinical observations of pharyngitis in the horse. J. Am. Vet. Med. Assoc., v.170, p.739-741, 1977.
MORLEY, P.S.; BROMBEREK, J.L.; SAULEZ, M.N. et al. Exercise-induced pulmonary haemorrhage impairs racing performance in Thoroughbred racehorses. Equine Vet. J. v.47, p.358-365, 2014.

OSLUND, K.L.; ADAMSON, G.; WU, R. Evaluation of MUC5AC expression and upregulation in airway epithelial cells of horses. Am. J. Vet. Res., v.71, p.690-696, 2010.

PARENTE, E.J. Treadmill endoscopy. Equine Vet. Educ., v.16, p.250-254, 2010.

PARENTE, E.J.; MARTIN B.B.; TULLENERS, E.P.; ROSS, M.W. Dorsal displacement of the soft palate in 92 horses during high-speed treadmill examination (1993-1998). Vet. Surg. v.31, p.507-512, 2002.

REED, S.M.; BAYLY, W.M.; SELLON, D.C. Equine internal medicine. St. Louis: Saunders Elsevier; 2010. 1488p.

ROY, M.F.; LAVOIE, J.P. Tools for the diagnosis of equine respiratory disorders. Vet. Clin. N. Am. Equine Pract., v.19, p.1-17. 2003.

RUSH, B.; MAIR, T.S. Equine respiratory diseases. Oxford: Blackwell Science, 2004. [18p].

SAULEZ, M.N.; GUMMOW, B. Prevalence of pharyngeal, laryngeal and tracheal disorders in thoroughbred racehorses, and effect on performance. Vet. Rec., v.165, p.431-435, 2009.

SEMECO, E.; RODRÍGUEZ, M.; BÁSALO, A. ARANGUREN, J.; FERNÁNDEZ, M. Prevalence of upper respiratory tract diseases in thoroughbred racehorses. Rev. Cient. FCV-LUZ, v.21, p.215-223, 2011.

SMITH, B.P. (Ed.). Large animal internal medicine. 5.ed. St. Louis: Elsevier, 2015. 1712p.

TETENS. J.; HUBERT. J.D.; EDDY, A.L.; MOORE RM. Dynamic tracheal collapse as a cause of exercise intolerance in a thoroughbred. J. Am. Vet. Med. Assoc., v.216, p.722-724, 685, 2000 .

WALLER, A.S.; PAILLOT. R.; TIMONEY. J.F. Streptococcus equi: a pathogen restricted to one host. J. Med. Microbiol., v.60, p.1231-1240, 2011. 